\title{
Chapter
}

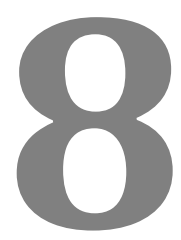

\section{SMALL MOLECULES TARGETING AT THE BACTERIAL CELL DIVISION PROTEIN FtSZ AS POTENTIAL ANTIMICROBIAL AGENTS}

\section{Ning Sun ${ }^{1,2}$ and Kwok-Yin Wong ${ }^{*}$}

${ }^{1}$ State Key Laboratory of Chirosciences and Department of Applied Biology and Chemical Technology, The Hong Kong Polytechnic University, Hunghom, Kowloon, Hong Kong, China

2 The Fifth Affiliated Hospital of Guangzhou Medical University, Guangzhou, China 


\section{Contents}

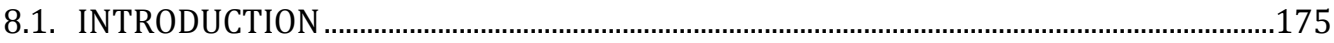

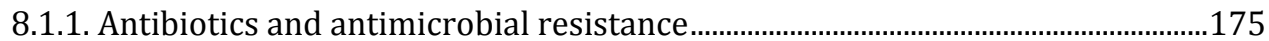

8.1.2. Bacterial cell division proteins as potential new drug targets ...............................175

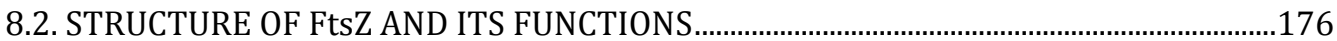

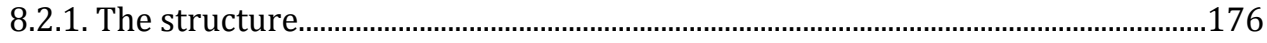

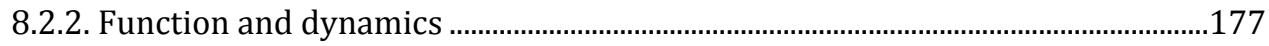

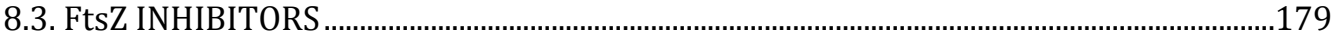

8.3.1. Natural products and their derivatives ......................................................................179

8.3.1.1 Berberine and its derivatives .........................................................................179

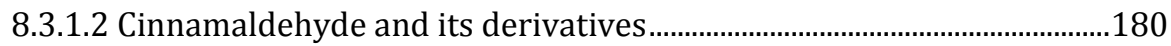

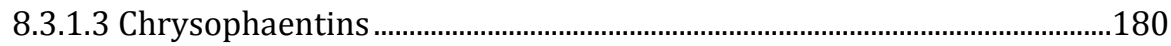

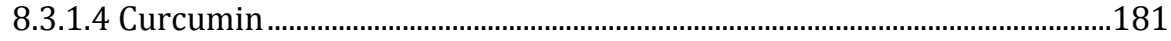

8.3.1.5 Viriditoxin ...................................................................................................... 181

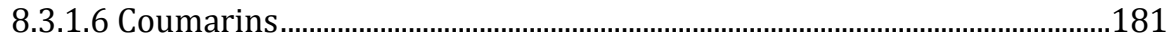

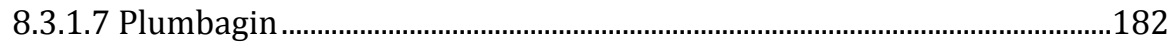

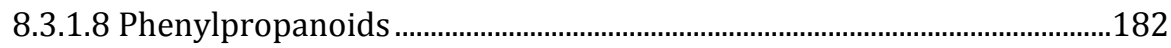

8.3.1.9 Dichamanetin and its derivative...................................................................183

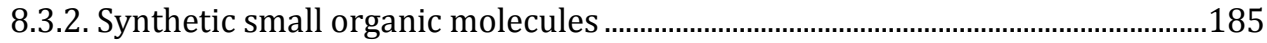

8.3.2.1 Benzamides .......................................................................................................185

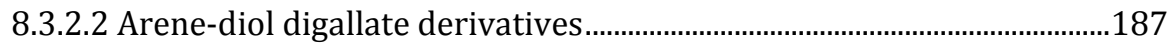

8.3.2.3 Pyrimidine-quinuclidine derivatives and analogs ....................................188

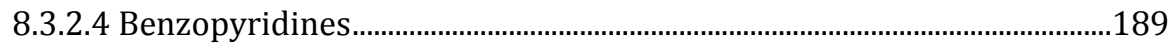

8.3.2.5 Rhodanine derivatives ................................................................................190

8.3.2.6 Pyridopyrazine and pyrimidothiazine analogs ...........................................191

8.3.2.7 Quinazoline derivatives ...............................................................................191

8.3.2.8 Taxane derivatives .........................................................................................192

8.3.2.9 Benzimidazole derivatives .............................................................................193

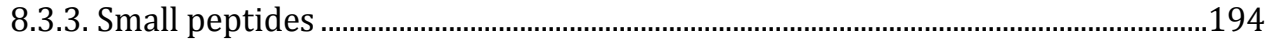

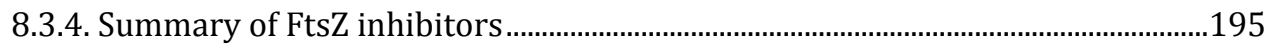

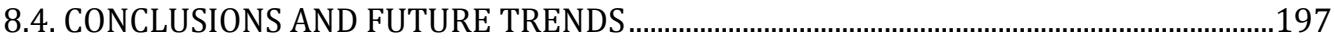

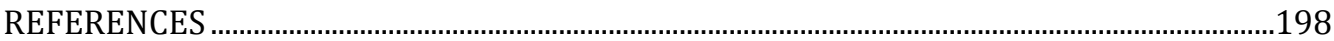




\subsection{INTRODUCTION}

\subsubsection{Antibiotics and antimicrobial resistance}

Since the discovery of the first antibiotic, penicillin, by Alexander Fleming in the 1930s [1], the following 40 years was the "golden era" of antibiotic research and most of the antibiotics currently in use were discovered and developed in that period [2]. The discovery of antibiotics was once regarded as the ultimate victory of the battle against bacterial infections but unfortunately the development of antimicrobial resistance to common antibiotics implies that this battle is endless. Nowadays, the treatment of bacterial infections has become more difficult because bacteria can develop resistance to antibiotics at an alarming speed [1-4]. Vancomycin-resistant Enterococcus faecium (VREF) and methicillin-resistant Staphylococcus aureus (MRSA) are two typical representatives of gram-positive bacteria that are resistant to conventional antibiotics including vancomycin and methicillin $[5,6]$. This situation is even more alarming in gram-negative bacteria. Bacteria express New Delhi metallobeta-lactamase-1 (NDM-1) are known to be highly resistant to most antibiotics. So far, only colistin and tigecycline are still effective against these superbugs $[7,8]$. Therefore, discovery of the next-generation antimicrobials with novel mechanisms of action is urgently needed $[4,9]$.

\subsubsection{Bacterial cell division proteins as potential new drug targets}

Cell division is an essential process for bacterial survival. During bacterial cell division, over 30 proteins assemble orderly to form the 'divisome' complex in such a way that the division process is controlled in a systematic manner. Many proteins involved in bacterial cell division are potential drug targets in antibiotic development. Among the bacterial cell division proteins, the filamenting temperature-sensitive mutant Z (FtsZ) is the first protein that assembles and initiates the cell division process. FtsZ is highly conserved in a wide range of bacteria [10-13]. During bacterial cell division, FtsZ assembles into a highly dynamic cytoskeleton scaffold called the Z-ring by undergoing guanosine-5'-triphosphate (GTP)-dependent polymerization, forming head-totail protofilaments and assembling into bundles at the site of septum formation [14-16]. Subsequently, downstream proteins that are responsible for septum formation and invagination of cell membrane are recruited by FtsZ to complete the bacterial cell division $[17,18]$. The high conservation and functional importance of FtsZ in bacterial cell division render it as an attractive target for the development of novel antibacterial agents. 


\subsection{STRUCTURE OF FtsZ AND ITS FUNCTIONS}

\subsubsection{The structure}

In FtsZ protein (Figure 1), there are two domains (the C-terminal and $\mathrm{N}$ terminal domains) $[19,20]$ separated by a central core helix (H7 helix) and a synergy loop (T7 loop). The N-terminal domain contains a nucleotide-binding pocket, while the C-terminal domain and T7 loop contain residues essential for the GTPase activity of the protein. During polymerization of FtsZ protein, an active site for GTP hydrolysis is formed by the nucleotide-binding site of one FtsZ monomer, and the T7 loop of another FtsZ monomer. In addition, at the tail of the long C-terminal extension, there are some functional sites which enable the FtsZ protein to distinguish other accessory proteins during cell division [21-24].

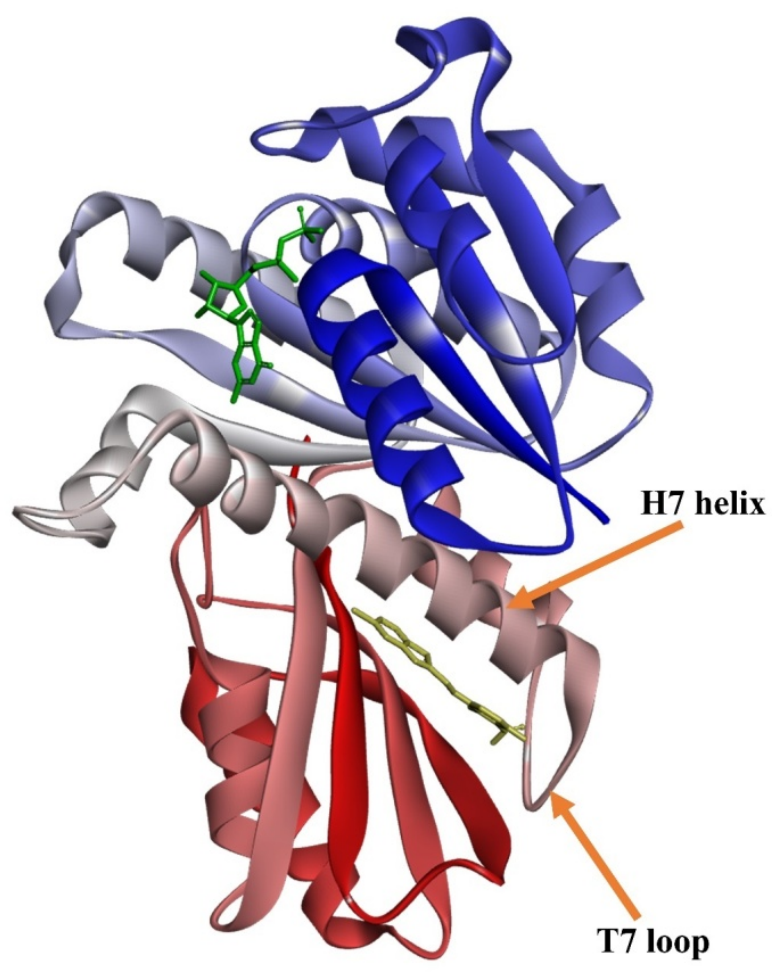

Figure 1. The structure of FtsZ monomer: the N-terminal domain

(blue-colored region), the C-terminal domain (red-colored region), and GDP in the nucleotide binding site (green-colored molecule). The yellow-colored molecule is PC190723, which is located at the interdomain cleft between $\mathrm{H} 7$ helix and C-terminal domain (PDB entry 4DXD) [25]. 
FtsZ is a structural homolog of the eukaryotic cytoskeleton protein tubulin. This is probably due to their similar structures and functions. To compare their structure, FtsZ and tubulin have a common fold and consisting of N-terminal and C-terminal domains linked by an $\alpha$-helix (H7) $[19,26]$. The conserved FtsZ residues and tubulin are both found in the nucleotide-binding region and this region is correlated to the formation of protofilament $[19,27]$. Tubulin is able to polymerize into microtubules and its function is to migrate the genetic materials to the poles of a dividing cell. The function of FtsZ is to polymerize to form Z-ring for controlling the division of a bacterial mother cell into daughter cells $[26,28,29]$. Furthermore, just as the microtubule assembly is influenced by microtubule associated proteins, the stability of FtsZ polymerization is controlled in vivo by bacterial cell division proteins such as FtsA, ZipA, and ZapA [28,30-34].

Although certain common features are found in FtsZ and tubulin, there are only $7 \%$ sequence identity at the protein level of the two proteins [35]. In fact, substantial differences can be found in the binding modes of their nucleotides $[36,37]$. Moreover, the amino acid sequence of C-terminus and the $\alpha$-helices contents are not the same in the two proteins [38]. In addition, tubulin forms $\alpha$ and $\beta$ heterodimers of different polarity, whereas the FtsZ polymer only contains FtsZ monomers in one form [39]. Furthermore, FtsZ protofilaments are different from the longitudinal associated tubulin subunits in that they associate with each other laterally to form an arc-shaped struture [40]. The differences in the structures of FtsZ and tubulin allow the development of new antibacterial agents with low eukaryotic cell cytotoxicity by targeting at the FtsZ protein.

\subsubsection{Function and dynamics}

Bacterial cell division starts with FtsZ polymerization with GTP in the middle of the cell. The polymers formed at the center of the cell then further develop bi-directionally and assemble into a helical structure known as Z-ring, which is highly dynamic [40-43]. Subsequently, various downstream proteins are recruited to the Z-ring structure for divisome complex formation. The Z-ring contracts to contribute to the septum formation in the final process of cell division (Figure 2) [44,45].

Both monomeric and oligomeric forms of FtsZ can be found in the cytoplasm of bacteria. For a single $E$. coli cell, there are nearly 15,000 copies of FtsZ and in the entire cell cycle the FtsZ concentration almost remains constant $[30,46]$. Interestingly, at a given time, there are only about $30 \%$ of FtsZ taking part in the Z-ring formation. These participated FtsZ molecules undergo rapid exchange with other FtsZ molecules in the cytoplasm at a half-life of approximately eight seconds $[47,48]$. Therefore, the resulting Z-ring is a dynamic structure balanced between assembly and disassembly [49]. 
A

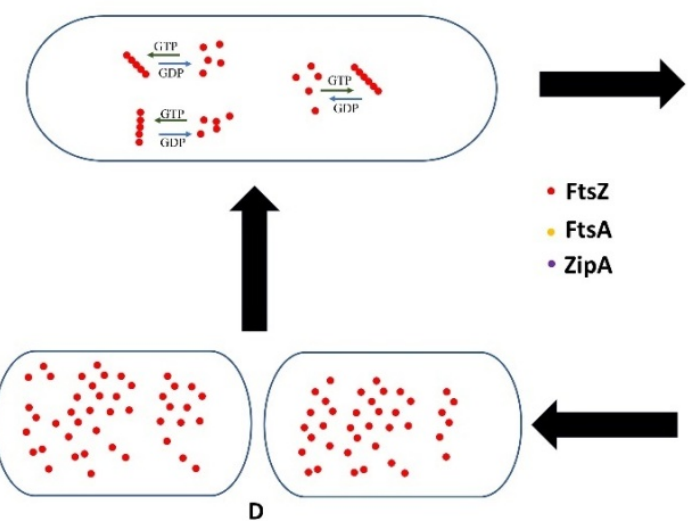

B
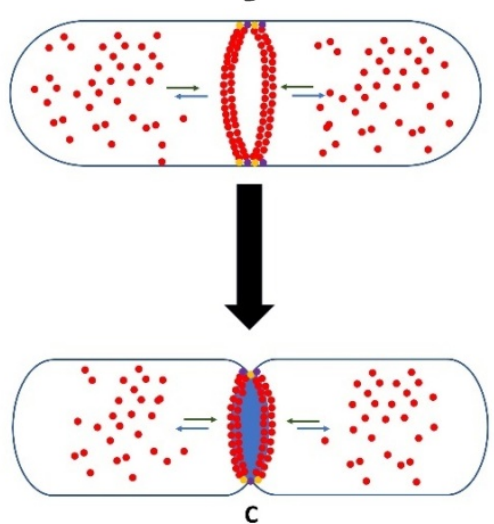

Figure 2. (A) Formation of protofilaments from FtsZ monomers polymerization in the presence of GTP; (B) Lateral interactions between protofilaments to form the Z-ring; the Z-ring is attached to the cell membrane via interaction with FtsA and ZipA; dynamic exchange of FtsZ monomers between the Z-ring and cytoplasm;

(C) Invagination of cell membranes resulting from the contraction of the Z-ring;

(D) Z-ring dissipates and the cell division is completed.

The FtsZ assembly process is started under the conditions that separation of nucleoids and replication of DNA are completed [30], and the required GTP concentration is above a critical concentration of $0.5-1 \mu \mathrm{M}$ [50-52]. When these external conditions are realized, FtsZ monomers bind with GTP and undergo cooperatively assembly in a head-to-tail manner to form protofilaments that are straight single-stranded protein filaments $4-5 \mathrm{~nm}$ in width) [53]. After the assembly, GTP is sandwiched in between the two adjacent FtsZ monomers. At the same time, the activity of GTPase is also triggered to hydrolyze GTP [54-56]. Then the protofilaments merge through the lateral interactions into condensates such as pairs, bundles, and sheets. As a result, the highly dynamic Z-ring structure is formed [36,50,57,58]. During polymerization, the T7 loop of FtsZ is pushed into the nucleotide-binding region of another FtsZ monomer. The catalytic residues of the T7 loop are positioned near the phosphate group of GTP to promote the hydrolysis reaction [59]. The protofilaments change their conformation from straight to curved when GTP is hydrolyzed to guanosine diphosphate (GDP) [60]. The hydrolysis of GTP provides the required energy for cell division. The conformation change of FtsZ protofilaments is also believed to transfer the mechanical force to the cell membrane for its invagination before cell division completion [60,61]. In addition, the process of GTP hydrolysis is associated to the de-polymerization of FtsZ [49]. In recent years, it has been reported that in some FtsZ-mutant cells, even when there is no detectable GTPase activity, the mutant cells can still show cell division ability and take the physiological role of division. For this reason, the hydrolysis reaction of GTP is not considered as 
the only energy source for the construction of the septum but is regarded as a promotive element in the symmetric invagination of cell division $[62,63]$.

The FtsZ subunits assembly can be observed at the mid-cell in a temporally regulated stage-specific manner. MinCDE system and Noc (B. subtilis)/SIma ( $E$. coli) are the regulatory factors to ensure the location of FtsZ assembly between the segregated chromosomes in the middle region of the cell but not at the cell poles $[18,64]$. It is believed that protofilaments annealing leads to the lateral interactions for most protofilaments [64]. It is also suggested that the lateral interactions are probably caused by the electrostatic forces of ions from the protofilaments [58]. Currently, the mechanism of protofilament assembly remains to be in dispute and needs to be further investigated [65].

For Z-ring formation, the FtsZ-interacting proteins play a very vital role in the process. In particular, FtsA and ZipA that bind to the C-terminal domain are the most essential proteins for proper cytokinesis [31,32]. FtsA is conserved in most bacteria and is able to displace ZipA. It is therefore regarded as a more important factor than ZipA for Z-ring integrity [31,32]. The formation of Z-ring is also influenced by some stabilizing proteins including SepF and ZapA, and destabilizing proteins like SulA and MinCD [42], as well as other factors such as glutamate [66], calcium [67], pH value, and the ionic strength [68].

\subsection{FtsZ INHIBITORS}

With the rising of drug-resistant bacteria, the development of new antibacterial agents with novel mechanism of action is highly desirable. FtsZ is a well-studied protein and is a potential new drug target. Several characteristics render FtsZ a potential target for the development of new antibacterial agents: (i) it plays an essential role in bacterial cell division [45]; (ii) the structure and function of FtsZ are conserved across bacterial species $[17,20]$; (iii) it is absent in eukaryotes [69,70]; (iv) its structural and biological properties are well studied. So far, there are no drugs on the market targeting at FtsZ, but many researchers have made great efforts in studying FtsZ targeting compounds and their studies revealed that FtsZ inhibitors can lead to bacterial cell death via inhibition of cell division [71-74]. Most of these inhibitors will be discussed in the following sections.

\subsubsection{Natural products and their derivatives}

\subsubsection{Berberine and its derivatives}

Berberine (1 in Figure 3) is a common natural alkaloid from Berberis. In 2008, Dasgupta and co-workers reported that berberine interacted with E. coli FtsZ by inhibiting the GTPase activity ( $\mathrm{IC}_{50} 16 \mu \mathrm{M}$ ) and assembly (IC $5010 \mu \mathrm{M}$ ) of 
FtsZ in a dose-dependent manner. Molecular modeling study suggested that the binding site of berberine overlapped with the GTP binding pocket in E. coli FtsZ [75].

Using a method of in silico structure-based design, Wong and co-workers synthesized a number of 9-phenoxyalkyl berberine derivatives, which were suggested to bind to the C-terminal interdomain cleft of $S$. aureus FtsZ. These derivatives inhibit the growth of MRSA and VRE with minimum inhibitory concentrations (MICs) of 2-8 $\mu \mathrm{g} \mathrm{mL}^{-1}$ and $4-16 \mu \mathrm{g} \mathrm{mL}^{-1}$, respectively. These compounds also exhibit moderate antimicrobial activity against the gramnegative strains such as E. coli with MIC of $32-128 \mu \mathrm{g} \mathrm{mL}^{-1}$. Among these derivatives, compound 2 (Figure 3 ) possessed the most potent antibacterial activity and inhibits the growth of MRSA and VRE with MICs of 2 and $4 \mu \mathrm{g} \mathrm{mL}^{-1}$, respectively. In addition, it can inhibit FtsZ polymerization and GTPase ${ }^{\left(I C_{50}\right.}$ $38 \mu \mathrm{g} \mathrm{mL}^{-1}$ ) in a dose-dependent manner. The results of transmission electron microscopy (TEM) images revealed that the compound reduced the size and thickness of FtsZ polymers significantly [76].

\subsubsection{Cinnamaldehyde and its derivatives}

Cinnamaldehyde (3 in Figure 3) is a natural aromatic compound derived from the stem bark of Cinnamomum cassia. It inhibits E. coli FtsZ GTPase activity and polymerization with $\mathrm{IC}_{50}$ values of $5.81 \mu \mathrm{M}$ and $6.86 \mu \mathrm{M}$, respectively. Molecular modeling and STD-NMR spectroscopy showed that cinnamaldehyde binds to FtsZ around the T7 loop in the C-terminal region [77].

Ma and co-workers synthesized serials of cinnamaldehyde derivatives and tested their antibacterial activity against Gram-positive and -negative bacteria. Some of them exhibited cell division inhibitory effect on S. aureus ATCC25923 in the concentration range of $0.25-4 \mu \mathrm{g} \mathrm{mL}^{-1}$. Compounds containing a 2methylbenzimidazolyl substitution at 1-position and 2,4-dichlorophenyl at the 3 -position exhibited the best activity (Compound 4). The results of biological assays revealed that the compounds can inhibit polymerization and GTPase activity of $S$. aureus FtsZ in a dose-dependent manner [78].

\subsubsection{Chrysophaentins}

Chrysophaentins A-H are natural products isolated from the marine chrysophyte alga Chrysophaeumtaylori. Bewley and co-workers found that chrysophaentins are effective against several Gram-positive bacterial strains. Among them, chrysophaentin A (5 in Figure 3) showed the best antibacterial activity against many drug-resistant bacteria. For examples, the MICs of this compound against MRSA and VRE are $1.5 \mu \mathrm{g} \mathrm{mL}^{-1}$ and $2.9 \mu \mathrm{g} \mathrm{mL}^{-1}$, respectively. In addition, chrysophaentin A was found to inhibit the GTPase activity of E. coli 
FtsZ with $\mathrm{IC}_{50}$ of $6.7 \mu \mathrm{g} \mathrm{mL}^{-1}$ and block FtsZ polymerization. STD-NMR experiment and competition assay indicated that chrysophaentin A interacted with FtsZ at the GTP binding site [79]. As a continued study, Bewley and coworkers synthesized hemi-chrysophaentin and reported that the reaction mechanism is similar to that of chrysophaentin A. In the GTPase assay, chrysophaentin fragment (Compound 6) exerted inhibition effect on the GTPase activity of $S$. aureus FtsZ with $\mathrm{IC}_{50}$ of $38 \pm 9 \mu \mathrm{M}$ and $E$. coli FtsZ of $37 \pm 7 \mu \mathrm{M}$. The result of fluorescence anisotropy test indicated a competitive binding of 6 with GTP in the nucleotide binding region [80].

\subsubsection{Curcumin}

Curcumin (7 in Figure 3) is a dietary polyphenolic compound extracted from the rhizomes of Curcuma longa. In Indian cooking, curcumin is commonly used as a spice and a coloring agent and is known to have antibacterial activity against a broad range of bacterial pathogens. Rai and co-workers reported that curcumin decreased light scattering intensity of FtsZ protofilaments in a dosedependent manner, indicating its inhibitory effect on the FtsZ polymerization. The results of GTPase assay indicated that the interaction of curcumin with FtsZ enhanced the GTPase activity but destabilized the FtsZ polymers [81]. Using computational docking, Roy and co-workers identified the possible binding sites of curcumin in E. coli FtsZ and B. subtilis FtsZ. Curcumin was predicted to interact with several amino acid residues in the GTP binding pocket [82].

\subsubsection{Viriditoxin}

Viriditoxin (8 in Figure 3) originates from Aspergillus viridinutans. It inhibits GTPase activity of $E$. coli FtsZ with $\mathrm{IC}_{50}$ of $7.0 \mu \mathrm{g} \mathrm{mL}^{-1}$ and FtsZ polymerization with an $\mathrm{IC}_{50}$ value of $8.2 \mu \mathrm{g} \mathrm{mL}^{-1}$. Morphological study revealed that viriditoxin can cause the elongation of $B$. subtilis cells. Moreover, viriditoxin displays strong antibacterial effect on a number of drug-resistant Gram-positive pathogens, like various strains of $S$. aureus (MIC $4-8 \mu \mathrm{g} \mathrm{mL}^{-1}$ ), E. faecalis and $E$. faecium (MIC 2-16 $\mu \mathrm{g} \mathrm{mL}^{-1}$ ). The induction of FtsZ expression in bacterial cells could increase the MIC value, suggesting that viriditoxin targets with FtsZ in these bacterial strains [83].

\subsubsection{Coumarins}

Coumarins are phytochemicals consisting of a benzopyrone core. Coumarin (9), scopoletin (10), and daphnetin (11) show moderate inhibitory effects on the polymerization and GTPase activity of FtsZ (Figure 1). Scopoletin inhibits 
FtsZ polymerization with an $\mathrm{IC}_{50}$ of $41 \mu \mathrm{M}$ and daphnetin with an $\mathrm{IC}_{50}$ of $73 \mu \mathrm{M}$. The GTPase activity was inhibited by scopoletin and daphnetin with $\mathrm{IC}_{50}$ values of $23 \mu \mathrm{M}$ and $57 \mu \mathrm{M}$, respectively. Molecular modeling studies of FtsZ and coumarins suggested that coumarins may bind to the T7 loop of FtsZ [84]. Furthermore, Doble and co-workers suggested that coumarins exhibit antibacterial activity against $M$. tuberculosis $\mathrm{H} 37 \mathrm{Rv}$ through inhibiting polymerization and GTPase activity of FtsZ [84].

\subsubsection{Plumbagin}

Plumbagin (12 in Figure 3) is a naphthoquinone derivative from the root of Plumbagozeylanica and is known to possess antibacterial activities against a number of bacteria. Panda and co-workers reported that plumbagin can disturb Z-ring formation in B. subtilis 168 cells and cause cell elongation without an apparent effect on nucleoid segregation. Their results indicate that the FtsZ assembly process may be inhibited by plumbagin. Biochemical studies showed that plumbagin can effectively inhibit the GTPase activity of FtsZ. For instance, $24 \mu \mathrm{M}$ plumbagin is able to inhibit $58 \%$ of the GTPase activity. Moreover, plumbagin inhibits the FtsZ polymerization of $B$. subtilis in a dosedependent manner. Thus, 2, 5, and $10 \mu \mathrm{M}$ of plumbagin can reduce FtsZ polymerization by $26 \%, 33 \%$, and $45 \%$, respectively. Computational analysis and mutagenesis assay suggested that the binding site of plumbagin may locate near the C terminal of B. subtilis FtsZ and residues D199and V307 may be involved in the interaction between plumbagin and FtsZ [85].

\subsubsection{Phenylpropanoids}

Phenylpropanoids are the secondary metabolites produced by plants against pathogens. These compounds possess moderate antimicrobial activities [86]. Eight phenylpropanoids were tested against E. coli FtsZ and were found to disturb GTPase activity of FtsZ in vitro. For example, $100 \mu \mathrm{M}$ chlorogenic and ferulic acids inhibited the GTPase activity by 46 and $34 \%$, respectively. Caffeic and p-coumaric acid reduce the GTPase activity by 23 and $29 \%$, respectively. Light scattering assays revealed that these compounds inhibit FtsZ polymerization in a dose-dependent manner. Chlorogenic acid, which is most active among the phenylpropanoids, has an $\mathrm{IC}_{50}$ of $69.55 \pm 3.6 \mu \mathrm{M}$. Caffeic acid, 2,4,5-trimethoxycinnamic acid, p-coumaric acid, and cinnamic acid have $\mathrm{IC}_{50} \mathrm{~S}$ of $105.96 \pm 6.3 \mu \mathrm{M}, 148.59 \pm 4.3 \mu \mathrm{M}, 189.53 \pm 3.7 \mu \mathrm{M}$, and $238.91 \pm 7.1 \mu \mathrm{M}$, respectively. 3,4-Dimethoxycinnamic acid, 2,4,5-trimethoxycinnamic acid, and eugenol were the least active compounds with $\mathrm{IC}_{50}>250 \mu \mathrm{M}$. Furthermore, morphological studies showed that these compounds can inhibit the bacterial cell division and induce cell elongation of $B$. subtilis 168 cells [87]. 


\subsubsection{Dichamanetin and its derivative}

Dichamanetin (13 in Figure 3) and its derivative, 2'"'-hydroxy-5"'benzylisouvarinol-B (14 in Figure 3), are polyphenolic compounds extracted from Uvariachamae and Xylopia Africana, respectively [88]. These natural products display antibacterial activity against many bacteria. Particularly, they possess potent antibacterial activity against $S$. aureus with MIC values of $0.8 \mu \mathrm{g} \mathrm{mL}^{-1}$ and $1.16 \mu \mathrm{g} \mathrm{mL}^{-1}$, respectively $[88,89]$. As a continuation of mechanistic study, Urgaonkar and co-workers evaluated the effects of dichamanetin on the GTPase activity of $E$. coli FtsZ and reported the inhibition $\mathrm{IC}_{50}$ values are $12.5 \mu \mathrm{M}$ and $8.3 \mu \mathrm{M}$, respectively [89]. 
<smiles>COc1ccc2cc3[n+](cc2c1OC)CCc1cc2c(cc1-3)OCO2</smiles>

Berberine (1)<smiles>O=C/C=C/c1ccccc1</smiles>

Cinnamaldehyde (3)<smiles>Cc1nc2ccccc2n1C(=O)/C=C/c1ccc(Cl)cc1Cl</smiles>

4<smiles>COC1=c2c(OCCCOc3ccc(Cl)cc3)c3c(cc2=[N+](Br)C=C3)C=C1</smiles>

2<smiles></smiles>

Chysophaentin A (5)<smiles>COc1cc(CC=C(Cl)Cc2cc(O)cc(O)c2)c(OC)cc1Cl</smiles>

6<smiles>COc1cc(/C=C/C(=O)/C=C(O)/C=C/c2ccc(O)c(OC)c2)ccc1O</smiles>

Curcumin (7)<smiles>COC(=O)CC1Cc2cc3c(-c4c(OC)cc(O)c5c(O)c6c(c(O)c45)C(=O)OC(CC(=O)OC)C6)c(O)cc(O)c3cc2C(=O)O1</smiles>

Viriditoxin (8)<smiles>O=c1cc(O)c2ccccc2o1</smiles>

Coumarin (9)<smiles>COc1cc2ccc(=O)oc2cc1C</smiles>

Scopoletin (10)<smiles>O=c1ccc2ccc(O)c(O)c2o1</smiles>

Daphnetin (11)<smiles>CC1=CC(=O)C2C(O)=CC=CC2C1=O</smiles>

Plumbagin (12)<smiles>O=C1C[C@H](c2ccccc2)Oc2c(Cc3ccccc3O)c(O)c(Cc3ccccc3O)c(O)c21</smiles>

Dichamanetin (13)<smiles>O=C1C[C@H](c2ccccc2)Oc2c(Cc3ccccc3O)c(O)c(Cc3cc(Cc4ccccc4O)ccc3O)c(O)c21</smiles>

2"'-hydroxy-5"-benzylisouvarinol-B (14)

Figure 3. The structures of FtsZ inhibitors from natural source 


\subsubsection{Synthetic small organic molecules}

\subsubsection{Benzamides}

3-Methoxybenzamide (3-MBA) (Figure 4) was reported a FtsZ inhibitor leading to cell elongation in B. subtilis [90]. In view of the advantages of 3-MBA such as low molecular mass and good ligand efficiency, Czaplewski and co-workers established a medicinal chemistry program to search for various 3-MBA derivatives [91]. They performed structure-activity relationship (SAR) study with 3-MBA based on more than 500 3-MBA congeners and eventually identified PC190723 (16) which possesses much better potency than the other 3-MBA derivatives. PC190723 exhibits effective antibacterial activity against $B$. subtilis and various strains of $S$. aureus, such as MRSA and multidrug resistant $S$. aureus (MDRSA). The MIC values were found to be as low as $1 \mu \mathrm{g} \mathrm{mL}^{-1}$. Moreover, PC190723 inhibits the GTPase activity of $S$. aureus FtsZ in a dosedependent manner with an $\mathrm{IC}_{50}$ value of $55 \mu \mathrm{g} \mathrm{mL} \mathrm{L}^{-1}$. In the cell morphology study, rod-shaped B. subtilis or spherical S. aureus treated with PC190723 exhibited cell elongation or enlargement. In addition, PC190723 was found to disturb Z-ring formation in the $B$. subtilis cells. Docking study showed that PC190723 binds to the interdomain cleft between C-terminal and H7 helix, which is consistent with the result of a mutation study [91]. Andreu and coworkers found that PC190723 inhibited GTPase activity of B. subtilis FtsZ through inducing FtsZ polymers into straight bundles and ribbons. The result suggested that PC190723 inhibit FtsZ via the stabilization of the FtsZ polymerization [92]. Lumb and co-workers also conducted some structural and biochemical analyses of $S$. aureus FtsZ with PC190723. The study pointed out that PC190723 shifted the structural equilibrium of FtsZ to a conformation with high-affinity [93]. From the co-crystal structure of PC190723 interacted with $S$. aureus FtsZ, the C-terminal domain was found to move in such a way that stabilization of FtsZ protofilaments was better than that of FtsZ monomers [93]. Therefore, PC190723 represents a new type of inhibitor targeting at FtsZ with high efficiency and possibility for further structural optimization.

Stokes etal. developed some PC190723 analogs (Figure 4), which bear a phenyloxazole group to replace the thiazolopyridine group and a substituted methylene group connecting to the oxazole and benzamide moieties. The $(4,5-$ disubstituted oxazolyl)-CH(R)-O-benzamides are able to enhance the antibacterial activity significantly against wild type $S$. aureus (Compound $\mathbf{1 7}$ in Figure 4, MIC is $0.03 \mu \mathrm{g} \mathrm{mL}^{-1}$ ). The C5 position of the oxazole moiety can be modified with alkyl, aryl or halogen substituents to achieve higher potency. In this series of compounds, 5-bromo- and 5-chlorooxazolyl analogs exhibit high activity against a mutant strain of $S$. aureus, G196A [94,95]. To increase the pharmacokinetic parameters of the compounds, polar groups such as alcohol, amine, carboxylic acid and heterocycles were incorporated to the pseudobenzylic position (-CH(R)-O- moiety). These polar groups increase the solubility and the metabolic stability of the compounds. However, when a gem- 
dimethyl group was introduced at the pseudo-benzylic position, it results in loss of activity, which suggests that chirality is a crucial factor in antibacterial activity. The enantiomers of compound 18 in Figure 4 (having $-\mathrm{CH}\left(\mathrm{CH}_{2} \mathrm{OH}\right)-0$ group) after isolated with chiral chromatography were tested for antibacterial activity. Surprisingly, (R)-(+)-enantiomer shows 128 times more effective than the (S)-(-)-enantiomer. In order to further increase the solubility of compound 18, a prodrug 19 was synthesized. The solubility of 19 was 2 -fold higher than its parent compound [94,95]

To further increase the pharmacological properties of PC190723, Pilch and coworkers synthesized 1-methylpiperidine-4-carboxamide TXY541 (20, Figure 4), which is a prodrug of PC190723. The compound was effective against MRSA [96]. Its solubility in an aqueous acidic vehicle $(10 \mathrm{mM}$ citrate, $\mathrm{pH}$ 2.6) is about 143 times higher than that of PC190723. The compound also showed efficacy in vivo via intravenous and oral administration using $S$. aureus infectious mice model. TXA541 showed a bactericidal mode of action against MRSA with a MBC/MIC ratio of 2. TXA707 (21) was also developed by adding a trifluoromethyl group instead of the chloro group in TXY541 and TXA709 (22) to overcome the CYP-mediated dechlorination/oxygenation [97]. The addition of trifluoromethyl group was able to improve metabolic stability substantially. The MIC value of TXA707 was $1 \mu \mathrm{g} \mathrm{mL}^{-1}$ against MRSA and VRSA. The $t_{1 / 2}$ of TXA707 following intravenous administration of TXA709 was $3.65 \mathrm{~h}$, while the $t_{1 / 2}$ of PC190723 following the intravenous administration of TXA541 was $0.56 \mathrm{~h}$. TXA709 thus displayed better pharmacokinetic properties by keeping its strong antibacterial activity and its efficacy in vivo. In a study of the mice model infected with MRSA ATCC 33591, a 2-log reduction in bacterial CFU can be found in the model treated with 120 or $160 \mathrm{mg} \mathrm{kg}^{-1}$ of TXA709 administered orally, while only about $0.5-\log$ reduction was found when orally administered $200 \mathrm{mg} \mathrm{kg}^{-1}$ of PC190723 [25,97]. 
<smiles>COc1cccc(C(N)=O)c1</smiles>

3-MBA (15)<smiles>NC(=O)c1c(F)ccc(OCc2nc3cc(Cl)cnc3s2)c1F</smiles>

PC190723 (16)<smiles>CCCc1oc(COc2ccc(F)c(C(N)=O)c2F)nc1-c1ccc(C(F)(F)F)cc1</smiles>

17<smiles>NC(=O)c1c(F)ccc(OC(CO)c2nc(-c3ccc(C(F)(F)F)cc3)c(Br)o2)c1F</smiles>

18<smiles>NC(=O)c1c(F)ccc(O[C@H](COC(=O)CCC(=O)O)c2nc(-c3ccc(C(F)(F)F)cc3)c(Br)o2)c1F</smiles><smiles>[R16][R16]([R16])([R16])[H]</smiles><smiles>[Y10][R16]#[R16]</smiles><smiles>CN1CCC(C(=O)NC=O)CC1</smiles><smiles>CNC(=O)c1c(F)ccc(OCc2nc3cc(C(F)(F)F)cnc3s2)c1F</smiles>

Figure 4. Structures of 3-MBA and its derivatives

\subsubsection{Arene-diol digallate derivatives}

In a search for small molecular inhibitors that can compete with GTP in FtsZ protein, Ruiz-Avila et al. selected a series of small molecules from virtual screening hits, literature and in-house compounds by docking into the $B$. subtilis FtsZ GTP binding site. The hits obtained were further examined by mant-GTP anisotropy. The results showed that UCM05 (23 in Figure 5), UCM44 (24 in Figure 5), and UCM53 (25 in Figure 5) can inhibit bacterial growth with MIC values of $100 \mu \mathrm{M}, 25 \mu \mathrm{M}$, and $13 \mu \mathrm{M}$ respectively. The binding modes of these compounds suggest that the inhibitory effects were contributed from the phenolic groups and the naphthalene core that occupied the phosphate and nucleic base binding sites of GTP. Moreover, all the three compounds can effectively induce cell elongation and disturb Z-ring formation in B. subtilis cells [98]. Based on the structure of these compounds, a number of small molecule inhibitors were synthesized and their activities against bacteria and FtsZ protein were evaluated. The most potent compound 26 (Figure 5) displays a strong binding affinity with FtsZ $\left(K_{\mathrm{d}} 0.5 \mu \mathrm{M}\right)$ and antibacterial activity against MRSA (MIC value of $7 \mu \mathrm{M}$ ). Most of arene-diol digallates at 
$100 \mu \mathrm{M}$ show little inhibition on tubulin polymerization, suggesting high selectivity to FtsZ [99].

\subsubsection{Pyrimidine-quinuclidine derivatives and analogs}

To identify hit compounds targeting at the GTP binding site of FtsZ, Wong and co-workers carried out a structure-based virtual screening of over 20,000 compounds, which contain natural products and their semisynthetic derivatives using the crystal structure of Methanococcus jannaschii FtsZ [100]. The ten top-ranked compounds from the screening were further tested for their GTPase inhibitory effect in vitro and antibacterial activity against pathogens. Among these compounds, compound 27 (Figure 5), which conatins a pyrimidine-quinuclidine moiety as the core structure, exhibits moderate GTPase inhibitory effect against $S$. aureus FtsZ $\left(\mathrm{IC}_{50} 317 \mu \mathrm{M}\right)$ and antibacterial activity against $S$. aureus and E. coli with MIC values of $449 \mu \mathrm{M}$ and $897 \mu \mathrm{M}$, respectively. The compound was selected as the hit compound for further in silico optimization. A homology modeling of $S$. aureus FtsZ was used for screening new pyrimidine-quinuclidine derivatives. The screening generated compound $\mathbf{2 8}$ which displays significantly activity improvement in the biological tests. The GTPase inhibitory effect ( IC $_{50} 37.5 \mu \mathrm{M}$ ) and antibacterial activity against $S$. aureus (MIC $24.6 \mu \mathrm{M}$ ) and E. coli (MIC $49.6 \mu \mathrm{M}$ ) of $\mathbf{2 8}$ were more than 10 times higher compared to that of $\mathbf{2 7}$ [100]. In addition, these derivatives were reported to selectively inhibit FtsZ over tubulin and restore susceptibility of MRSA (ATCC BAA-41) to $\beta$-lactam antibiotics [101].

Employing pyrimidine-quinuclidine scaffold as a template, Wong and coworkers successfully synthesized 99 amine-linked 2,4,6-trisubstituted pyrimidine derivatives and investigated their biological activities. The results of antimicrobial susceptibility assay against $S$. aureus strains confirmed that these compounds possessed potent anti-staphylococcal activity (MIC ranged from 3-8 $\mu \mathrm{g} \mathrm{mL}^{-1}$ ). Biochemical studies of compound 14av_amine16 (29) by STD-NMR, light scattering and GTPase activity assay with $S$. aureus FtsZ revealed that it interacts with the FtsZ protein via inhibiting polymerization and GTPase activity of FtsZ. Furthermore, mislocalization of the Z-ring and filamentous cell phenotype of $B$. subtilis suggested that $\mathbf{2 9}$ is a FtsZ targeting compound. The compound also exhibits low frequency of resistance on S. aureus and low toxicity against Galleria mellonella larvae [102]. 
<smiles>CCCCCC(C)(C)C</smiles><smiles>CC(C)(C)C</smiles><smiles>CC(C)(C)C</smiles><smiles>O=C(Cc1cc(OC(=O)c2ccc(O)c(Cl)c2)cc(-c2ccccc2)c1)c1ccc(O)c(Cl)c1</smiles><smiles>Cc1nc(-c2cccs2)cc(C23CC4CC(C2)N(C4)C3CNC(=O)CCCC(=O)O)n1</smiles><smiles>CCC(CC)c1cc(C2CC3CC2CN3CN)nc(-c2ccncc2)n1</smiles><smiles>CCC(CC)c1cc(CCN2CCCN(Cc3ccc(C(F)(F)F)cc3)CC2)nc(-c2ccncc2)n1</smiles>

Figure 5. Structures of arene-dial digallates and pyrimidinequinuclidinederivativs

\subsubsection{Benzopyridines}

LaVoie and co-workers studied the effects on the antibacterial activity of a number of berberine derivatives having an aryl substituent located at the 2and 12-position [103]. The results suggested that addition of biphenyl substituent at either 2- or 12-position of berberine derivatives dramatically improves its antibacterial activity against $S$. aureus and E. faecalis. Compound 30 with a 2-biphenyl substituent (Figure 6) exhibited the best activity against MRSA (ATCC 33591) and vancomycin-resistant E. faecalis with MIC values of $0.5 \mu \mathrm{g} \mathrm{mL}-1$ and $2 \mu \mathrm{g} \mathrm{mL}^{-1}$ respectively. Moreover, in the light scattering assay, 
30 was found to significantly increase the light signal in compared with the control, indicating its stimulation of FtsZ polymerization [103].

It has been reported that the addition of a hydrophobic substituent to sanguinarine can enhance the antibacterial activity dramatically [103]. LaVoie and co-workers further simplified their common scaffolds to produce a new 3phenylisoquinoline core. The derivatives based on 3-phenylisoquinoline and 3phenylisoquinolinium core were thus synthesized for antibacterial activity evaluation [104]. Their results indicated that the quaternary isoquinolinium derivatives exhibited higher activity than the corresponding non-quaternary isoquinolines. In addition, the lipophilicity of the substituent at the 3'-position contributed to the antibacterial efficacy. Compound $\mathbf{3 1}$ (in Figure 6) exerted potent inhibition of MRSA and VRE with MIC values of $1 \mu \mathrm{g} \mathrm{mL}^{-1}$ and $4 \mu \mathrm{g} \mathrm{mL}^{-1}$ respectively. Moreover, the binding properties of these compounds to $S$. aureus FtsZ were monitored by intrinsic fluorescence spectroscopy. The dissociation constants were found to be in the range of 1 to $10 \mu \mathrm{M}$. In addition, this compound showed little effect on the mammalian tubulin and low cytotoxicity to mammalian cells [104].

Based on the above-mentioned study of quinoline derivatives, Sun et al. studied the antibacterial activity of $N$-methylbenzoindolo[3,2- $b]$-quinoline and $N$-methylbenzofuro[3,2-b]-quinoline derivatives, as well as a thiazole orange quinolin-1-ium iodide derivative[105,106]. The results revealed that these compounds possess potent antibacterial activity against bacterial strains including MRSA and VRE. The results of biological study suggested that these compounds disrupt the dynamic assembly of FtsZ protein and Z-ring formation through inhibiting GTPase activity of FtsZ $[105,106]$.

\subsubsection{Rhodanine derivatives}

OBTA (3-\{5-[4-oxo-2-thioxo-3-(3-trifluoromethylphenyl)-thiazolidin-5-ylidenemethyl]-furan-2-yl\}-benzoic acid, 32 in Figure 6) was found to enhance FtsZ assembly in an in vitro screening of 81 compounds having 29 different structural scaffolds on FtsZ polymerization [107]. OBTA can reduce the GTPase activity of FtsZ and improve the polymerization of FtsZ. The binding affinity study revealed that OBTA interacted with FtsZ at a dissociation constant of $15 \mu$ M. Furthermore, OBTA induced bacterial cell elongation and disturbed Zring formation in bacteria. In addition, OBTA possesses a potent antibacterial activity, and shows little cytotoxic effects on mammalian cells [107]. The results indicate that OBTA may be a potential lead compound for further development of FtsZ inhibitors.

Panda and co-workers screened a library of 151 rhodanine derivatives in an attempt to discover new FtsZ inhibitors [108]. Among these derivatives, CCR11 (33 in Figure 6) could exert inhibition on B. subtilis with an MIC of $3 \mu \mathrm{M}$ and induce the elongation of $B$. subtilis cells. The results of biological assays showed that CCR-11 could inhibit the GTPase activity and polymerization of FtsZ. The 
influences on Z-ring, nucleoids and membrane were further examined in elongated B. subtilis. The results showed that CCR-11 can perturb Z-ring formation effectively without any impairment of nucleoids and membrane. From the docking study, CCR-11 is predicted to bind to a cavity near the T7 loop. The binding energies estimated theoretically are comparable to the binding constant $(1.5 \mu \mathrm{M})$ determined experimentally. With regard to the selectivity of this compound, the effects on mammalian cells showed that the cytotoxicity of CCR-11 is low [108].

\subsubsection{Pyridopyrazine and pyrimidothiazine analogs}

Since FtsZ shares some common features with eukaryotic tubulin, Reynolds and co-workers screened FtsZ-targeting compounds with similar structures to the anti-tubulin molecules in order to find anti-tuberculosis drugs [109]. Their study led to the discovery of $\mathbf{3 4}$ and $\mathbf{3 5}$ (Figure 6) which showed active effects on the polymerization of $M$. tuberculosis FtsZ with $\mathrm{IC}_{50}$ values of $34.2 \mu \mathrm{M}$ and $38.1 \mu \mathrm{M}$, respectively. In addition, these two compounds have a strong antituberculosis activity against $M$. tuberculosis H37Ra with MIC values of $0.25 \mu \mathrm{g} \mathrm{mL}^{-1}$ and $2 \mu \mathrm{g} \mathrm{mL}^{-1}$ [109]. As a continued study, Reynolds and coworkers further investigated the biological activities by using pyridopyrazine and pyrimidothiazine analogs [110]. The results showed that most of the compounds possess strong antimicrobial activity. However, they exhibited high cytotoxicity on mammalian cells. The SAR study revealed that pyridopyrazine derivatives possessing the heteroaromatic substituents at the C6 and $\mathrm{C} 7$ positions were more potent than the other compounds. In addition, a carbamate group substituted at the $\mathrm{C} 2$ position was critical for having better biological activity. Most of the compounds exhibit specific inhibitory effects on FtsZ polymerization without any effect on tubulin. Compounds 34 and 36 exhibited excellent antibacterial activity against $M$. tuberculosis $\mathrm{H} 37 \mathrm{Rv}$ with MIC values smaller than $0.19 \mu \mathrm{M}$ and a moderate inhibitory activity against $M$. tuberculosis FtsZ polymerization ( $\mathrm{IC}_{50}$ around $34 \mu \mathrm{M}$ ). Moreover, 34 shows positive effects on the acute TB infectious mice model. Pyrimidothiazine analogs of $\mathbf{3 5}$ were also synthesized and evaluated but were less potent than 35 [110].

\subsubsection{Quinazoline derivatives}

Zantrin Z3 (37 in Figure 6), a quinazoline derivative, was reported as a GTPase inhibitor of FtsZ with an $\mathrm{IC}_{50}$ of $24 \mu \mathrm{M}$ by Margalit and co-workers through a high throughput screening assay [111]. This compound was reported to perturb Z-ring assembly in E. coli cells and cause lethality to a variety of bacteria in broth cultures [111]. To develop reliable and valuable new FtsZ inhibitors, Shaw and co-workers preformed a broad biochemical crosscomparison of many known FtsZ inhibitors for the selection of reliable 
molecular scaffolds for further structural advancement. Modification of Zantrin $\mathrm{Z3}$ gave 38 (in Figure 6), a compound with an $\mathrm{IC}_{50}$ value of $12 \mu \mathrm{M}$ for the GTPase inhibition of FtsZ [112]. As a continued study, several quinazoline analogs were synthesized and examined for their biological activity. The SAR study discovered that benzo[g]quinazoline of Zantrin Z3 could be substituted by a smaller quinazoline while the 4-chlorostyryl moiety was critical for inhibitory effect on GTPase activity of FtsZ. Among these analogs, 39 (in Figure 6) having an ammonium salt side chain shows the best potency against GTPase of FtsZ with an IC ${ }_{50}$ of $9 \mu \mathrm{M}$ [113].<smiles></smiles>

30<smiles></smiles>

31
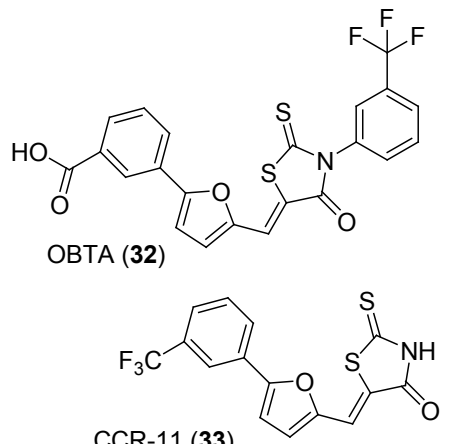

(33)<smiles></smiles><smiles>CCN(CC)CCNc1nc(/C=C/c2ccc(Cl)cc2)nc2cc3ccccc3cc12</smiles><smiles>CN(C)CCNc1nc(/C=C/c2ccc(Cl)cc2)nc2cc3ccccc3cc12</smiles><smiles>NCCNc1nc(/C=C/c2ccc(Cl)cc2)nc2cc3ccccc3cc12</smiles>

Figure 6. Structures of benzopyridines, rhodanine derivatives, pyridopyrazine and pyrimidothiazine analogs, and quinazoline derivatives

\subsubsection{Taxane derivatives}

Modification of taxane-derived molecules was also conducted in order to target FtsZ more favorably than tubulin. The main scaffold of taxane polycyclic core was kept unchanged in this study. SB-RA-2001 (40 in Figure 7) shows differences from paclitaxel (41 in Figure 7) mainly in two parts: (i) the alcohol 
at $\mathrm{C}-10$ without the acetyl group; (ii) an unsaturated ester replaces the $\alpha$ hydroxy- $\beta$-amido ester at C-13 [114]. These structural modifications resulted in better inhibition of $B$. subtilis FtsZ activity and showed antibacterial activity against both $B$. subtilis and $M$. smegmatis. However, it is highly cytotoxic towards mammalian cells. As a continued study, Ojima et al. disclosed that the conjugated ester group when it is coupled with a ring-opened core (TRA 10a (42 in Figure 7) or 10b (43 in Figure 7)) can enhance the potency of taxanederived small molecule targeting at $M$. tuberculosis FtsZ. Moreover, these compounds are clearly much less cytotoxic than paclitaxel (200-1,000 times less toxic) and $\mathbf{4 0}$ against mammalian cells [115].

\subsubsection{Benzimidazole derivatives}

Albendazole and thiabendazole are known tubulin inhibitors [116]. Previous reports revealed that these two benzimidazole derivatives inhibits septation of E. coli and M. tuberculosis cells leading to cell elongation and death $[116,117]$. Through structural analysis of these compounds, Ojima and co-workers synthesized a number of new small organic molecules with the benzimidazole scaffold (Figure 7) and evaluated their antimicrobial activity against M. tuberculosis H37Rv. Among these compounds, 44 and 45 (Figure 7) were found to display MIC values lower that $1 \mu \mathrm{g} \mathrm{mL}^{-1}$ without any significant toxicity $\left(\mathrm{IC}_{50}>200 \mu \mathrm{M}\right.$ ) against Vero cells [118]. Further investigation revealed that these compounds also showed similar potency against the drug-resistant M. tuberculosis strains. They showed a dose-dependent inhibition of FtsZ polymerization and exhibited a very strong improvement on the GTPase activity. TEM and SEM analyses of M. tuberculosis FtsZ and cells revealed that these compounds can perturb the size and thickness of FtsZ polymers and induce cell filamentation.

Ojima and co-workers further conducted a structural modification based on the reported lead compounds $\mathbf{4 4}$ and $\mathbf{4 5}$ by optimizing the nitrogen substituents at the 5- and 6-position while keeping the cyclohexyl group at the 2-position unchanged. They thus discovered several new compounds having MIC values that are below $1 \mu \mathrm{g} \mathrm{mL}^{-1}$ against M. tuberculosis H37Rv. Among these compounds, 46 and 47 (Figure 7) were reported to effectively inhibit clinical isolates of M. tuberculosis possessing different resistance profiles, with MIC values ranged from 0.06 to $0.16 \mu \mathrm{g} \mathrm{mL}-1$. Moreover, light scattering assay and TEM analyses indicated that these compounds obviously inhibited polymerization of $M$. tuberculosis FtsZ [119]. From all these results, it was suggested that the antimicrobial activity of these trisubstituted benzimidazoles can be attributed to their interaction with $M$. tuberculosis FtsZ. To evaluate the drug-like properties of these compounds, they studied the stability and in vivo susceptibility of the representative compound 48 (Figure 7). In the study, 48 showed outstanding stability in liver microsomes and human plasma. In addition, $\mathbf{4 8}$ was efficacious in the tuberculosis (TB) infectious animal model 
[120]. The results suggested that these tri-substituted benzimidazoles can be further optimized for development of novel antibacterials targeting FtsZ.

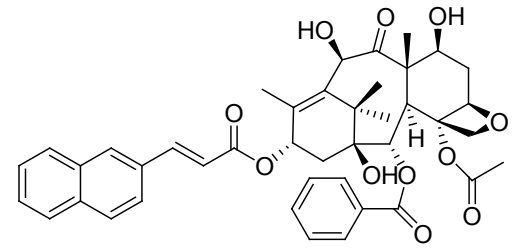

SB-RA-2001 (40)

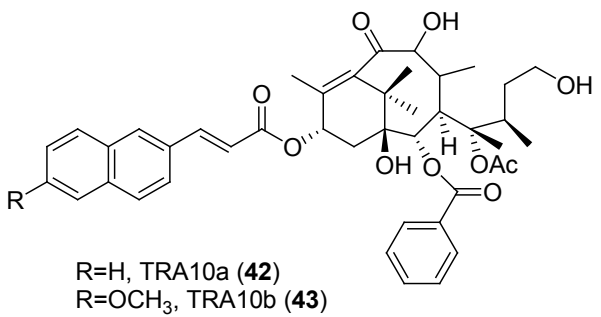

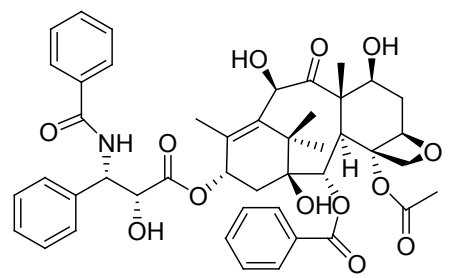

Paclitaxel (41)<smiles>CCCCOC(=O)Nc1cc2nc(C3CCCCC3)[nH]c2cc1N(CC)CC</smiles><smiles>CCCCOC(=O)Nc1cc2nc(C3CCCCC3)[nH]c2cc1N1CCCC1</smiles><smiles>CCCCOC(=O)Nc1cc2nc(C3CCCCC3)[nH]c2cc1N(C)C</smiles><smiles>[C+]#Cc1cc2nc(C3CCCCC3)[nH]c2cc1N(C)C</smiles>

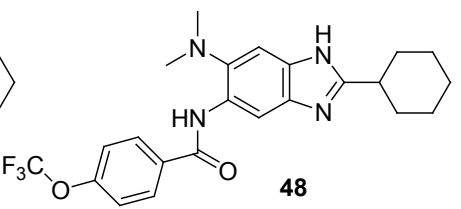

Figure 7. Structures of taxane and benzimidazole derivatives

\subsubsection{Small peptides}

A cathelin-related antimicrobial peptide (CRAMP) of 37 amino acid residues was found in multicellular organisms and reported to provide innate immunity to fight against microbes. CRAMP induces elongation of bacterial cells, indicating that it inhibits bacterial cytokinesis [121]. Recently, Ray et al. reported that a truncated version of CRAMP (GEKLKKIGQKIKNFFQKL, 16-33) exhibited antibacterial activity and FtsZ inhibitory effects [122]. This peptide can totally inhibit the growth of B. subtilis and E. coli at concentration of $20 \mu \mathrm{M}$ and $50 \mu \mathrm{M}$, respectively. Light scattering assay of FtsZ with this peptide showed a dose-dependent inhibitory effect on FtsZ polymerization. By contrast, CRAMP does not affect tubulin polymerization. In addition, this 
peptide also decreases GTPase activity of FtsZ, and inhibits cell division and Zring formation of $B$. subtilis, leading to cell elongation.

Using computational alanine scanning (CAS), Pieraccini et al. identified the hot spot on the protein-protein interface between FtsZ subunits and used the derived interactions map to select an octapeptide corresponding to an FtsZ subsequence, which could interfere with FtsZ self-assembly. This peptide was then modified through two different schemes of cyclisation to constrain its helical geometry. These cyclic peptides are notably successful in inhibiting the rapid initial polymer formation and causing de-polymerization in response to the reduction in GTP in the initial steady phase of polymerization. These peptides interfere with both the assembly and the enzyme activity of $E$. coli FtsZ [123].

\subsubsection{Summary of FtsZ inhibitors}

A summary of the above-mentioned FtsZ inhibitors, bacterial strains investigated, tentative binding sites, and their mode of action is given in Table 1. Since only PC 190723 and its analogs have co-crystals with FtsZ protein, more information on the structural biology of inhibitors with the FtsZ protein is needed in order to promote structure-based rational design of new small molecules. Nevertheless, the putative binding sites have been discussed with the potent compounds and their possible mechanisms of action have also been proposed based on various biochemical studies.

Table 1. Summary of representative FtsZ inhibitors and the possible mode of action

\begin{tabular}{c|c|c|c|c}
\hline Compound & $\begin{array}{c}\text { Organism } \\
\text { studied }\end{array}$ & $\begin{array}{c}\text { MIC } \\
(\boldsymbol{\mu \mathbf { g ~ m L }} \mathbf{- 1})\end{array}$ & $\begin{array}{c}\text { Tentative } \\
\text { Binding site }\end{array}$ & Mode of action \\
\hline Berberine [75] & $\begin{array}{c}\text { B. subtilis; } \\
\text { E. coli }\end{array}$ & $\begin{array}{c}100 \\
>400\end{array}$ & $\begin{array}{c}\text { Hydrophobic } \\
\text { core of GTP } \\
\text { binding site }\end{array}$ & $\begin{array}{c}\text { Inhibits GTPase } \\
\text { activity of } \text { E. coli } \\
\text { FtsZ }\end{array}$ \\
\hline $\begin{array}{c}\text { Berberine } \\
\text { derivative (2) } \\
\text { [76] }\end{array}$ & MRSA; & 2 & $\begin{array}{c}\text { Interdomain } \\
\text { cleft }\end{array}$ & $\begin{array}{c}\text { Inhibits GTPase } \\
\text { activity and } \\
\text { polymerization of } S . \\
\text { aureus } \text { FtsZ }\end{array}$ \\
\hline $\begin{array}{c}\text { Cinnamaldehyde } \\
\text { [77] }\end{array}$ & B. subtilis; & 4 & T7 loop & $\begin{array}{c}\text { Inhibits GTPase } \\
\text { activity and } \\
\text { polymerization of } E \text {. coli } \\
\text { coli FtsZ }\end{array}$ \\
\hline $\begin{array}{c}\text { Cinnamaldehyde } \\
\text { derivative (4) } \\
\text { [78] }\end{array}$ & MRSA & 4 & T7 loop & $\begin{array}{c}\text { Inhibits GTPase } \\
\text { activity and } \\
\text { polymerization of } S . \\
\text { aureus } \text { FtsZ }\end{array}$ \\
\hline
\end{tabular}


Table 1. (continued)

\begin{tabular}{|c|c|c|c|c|}
\hline Compound & $\begin{array}{c}\text { Organism } \\
\text { studied }\end{array}$ & $\begin{array}{c}\text { MIC } \\
\left(\mu \mathrm{g} \mathrm{mL}^{-1}\right)\end{array}$ & $\begin{array}{c}\text { Tentative } \\
\text { Binding site }\end{array}$ & Mode of action \\
\hline $\begin{array}{c}\text { Chrysophaetin A } \\
\text { [79] }\end{array}$ & $\begin{array}{l}\text { MRSA; } \\
\text { VRE }\end{array}$ & $\begin{array}{l}1.5 \\
2.9\end{array}$ & $\begin{array}{l}\text { GTP binding } \\
\text { site }\end{array}$ & $\begin{array}{c}\text { Inhibits GTPase } \\
\text { activity and } \\
\text { polymerization of } E \text {. } \\
\text { coli } \text { FtsZ }\end{array}$ \\
\hline Curcumin [82] & $\begin{array}{l}\text { B. subtilis; } \\
\quad \text { E. coli }\end{array}$ & $\begin{aligned} & 37 \\
> & 200\end{aligned}$ & $\begin{array}{l}\text { GTP binding } \\
\text { site }\end{array}$ & $\begin{array}{l}\text { Increases GTPase } \\
\text { activity and } \\
\text { destabilizes FtsZ } \\
\text { polymerization }\end{array}$ \\
\hline Viriditoxin [83] & $\begin{array}{l}\text { S. aureus; } \\
\text { E. faecium }\end{array}$ & $\begin{array}{l}4-8 \\
2-16\end{array}$ & Unknown & $\begin{array}{c}\text { Inhibits GTPase } \\
\text { activity and } \\
\text { polymerization of } E \text {. } \\
\text { coli FtsZ }\end{array}$ \\
\hline Coumarins [84] & $\begin{array}{l}\text { B. subtilis; } \\
\text { M. } \\
\text { tuberculosis }\end{array}$ & $\begin{array}{l}100 \\
>100\end{array}$ & T7 loop & $\begin{array}{c}\text { Inhibits GTPase } \\
\text { activity and } \\
\text { polymerization of } \\
\text { FtsZ }\end{array}$ \\
\hline Plumbagin [85] & $\begin{array}{l}\text { B. subtilis; } \\
\quad \text { E. coli }\end{array}$ & $\begin{array}{c}48 \\
>100\end{array}$ & T7 loop & $\begin{array}{c}\text { Inhibits GTPase } \\
\text { activity and } \\
\text { polymerization of } B \text {. } \\
\text { subtilis FtsZ }\end{array}$ \\
\hline $\begin{array}{l}\text { Dichamanetin } \\
\text { and } 14 \text { [89] }\end{array}$ & S. aureus & $0.8 ; 1.16$ & Unkown & $\begin{array}{c}\text { Inhibits GTPase } \\
\text { activity and of } E \text {. coli } \\
\text { FtsZ }\end{array}$ \\
\hline $\begin{array}{c}\text { PC190723 } \\
{[25,91]}\end{array}$ & $\begin{array}{l}\text { S. aureus; } \\
\text { MRSA }\end{array}$ & 1 & $\begin{array}{l}\text { Interdomain } \\
\text { cleft between } \\
\text { C-terminal } \\
\text { and H7 Helix }\end{array}$ & $\begin{array}{c}\text { Stabilizes FtsZ } \\
\text { polymerization }\end{array}$ \\
\hline $\begin{array}{c}\text { Arene-diol } \\
\text { digallate (26) } \\
{[98]} \\
\end{array}$ & MRSA & $7 \mu \mathrm{M}$ & $\begin{array}{l}\text { GTP binding } \\
\text { site }\end{array}$ & $\begin{array}{c}\text { Inhibits GTPase } \\
\text { activity }\end{array}$ \\
\hline $\begin{array}{c}\text { Pyrimidine- } \\
\text { quinuclidine } \\
\text { derivative (27) } \\
\text { [100] }\end{array}$ & $\begin{array}{l}\text { S. aureus; } \\
\quad \text { E. coli }\end{array}$ & $\begin{array}{l}12 ; \\
24\end{array}$ & $\begin{array}{l}\text { GTP binding } \\
\text { site }\end{array}$ & $\begin{array}{c}\text { Inhibits GTPase } \\
\text { activity and } \\
\text { polymerization of } S \text {. } \\
\text { aureus FtsZ }\end{array}$ \\
\hline $\begin{array}{c}\text { Benzopyridine } \\
\text { derivative (30) } \\
{[103]} \\
\end{array}$ & $\begin{array}{l}\text { MRSA; } \\
\text { VRE }\end{array}$ & $\begin{array}{c}0.5 \\
2\end{array}$ & Unknown & $\begin{array}{l}\text { Increases FtsZ } \\
\text { polymerization }\end{array}$ \\
\hline $\begin{array}{c}\text { Rhodanine } \\
\text { derivatives } \\
{[107,108]}\end{array}$ & B. subtilis; & $1-2$ & T7 loop & $\begin{array}{l}\text { Increase FtsZ } \\
\text { polymerization }\end{array}$ \\
\hline
\end{tabular}


Table 1. (continued)

\begin{tabular}{|c|c|c|c|c|}
\hline Compound & $\begin{array}{l}\text { Organism } \\
\text { studied }\end{array}$ & $\begin{array}{c}\text { MIC } \\
\left(\mu \mathrm{g} \mathrm{mL}^{-1}\right)\end{array}$ & $\begin{array}{c}\text { Tentative } \\
\text { Binding site }\end{array}$ & Mode of action \\
\hline $\begin{array}{l}\text { Pyridopyrazine } \\
\text { and } \\
\text { pyrimidothiazine } \\
\text { analogs [109] }\end{array}$ & $\begin{array}{c}M . \\
\text { tuberculosis }\end{array}$ & $0.25-2$ & Unknown & $\begin{array}{l}\text { Inhibit the } \\
\text { polymerization of } M \text {. } \\
\text { tuberculosis } \text { FtsZ }\end{array}$ \\
\hline Zantrin Z3 [111] & $\begin{array}{l}\text { S. aureus; } \\
\quad \text { E. coli }\end{array}$ & $\begin{array}{l}5 \\
5\end{array}$ & Unknown & $\begin{array}{l}\text { Stabilizes FtsZ } \\
\text { polymerization }\end{array}$ \\
\hline $\begin{array}{c}\text { Taxane derivative } \\
{[115]}\end{array}$ & $\begin{array}{c}M . \\
\text { tuberculosis }\end{array}$ & $\begin{array}{c}2.5- \\
10 \mu \mathrm{M}\end{array}$ & $\begin{array}{l}\text { C-terminal } \\
\text { region } \\
\text { around T7 } \\
\text { loop } \\
\end{array}$ & $\begin{array}{l}\text { Increases FtsZ } \\
\text { polymerization }\end{array}$ \\
\hline $\begin{array}{c}\text { Benzimidazole } \\
\text { derivatives } \\
{[118,120]}\end{array}$ & $\begin{array}{c}M . \\
\text { tuberculosis }\end{array}$ & $0.06-0.16$ & Unknown & $\begin{array}{l}\text { Increase GTPase } \\
\text { activity, and inhibit } \\
\text { FtsZ polymerization }\end{array}$ \\
\hline CRAMP [122] & $\begin{array}{l}\text { B. subtilis; } \\
\quad \text { E. coli }\end{array}$ & $\begin{array}{l}20 \mu \mathrm{M} \\
50 \mu \mathrm{M}\end{array}$ & Near T7 loop & $\begin{array}{c}\text { Disrupts FtsZ-FtsZ } \\
\text { interaction }\end{array}$ \\
\hline
\end{tabular}

\subsection{CONCLUSIONS AND FUTURE TRENDS}

Infections caused by drug-resistant bacteria, in particular multidrug resistant strains, are a great pending threat to human health. However, most of the clinically used drugs are still limited to classical antibacterial agents such as those that target at the penicillin binding protein. Thus, there is an urgent need to develop new generation of antibacterial agents that have a different mechanism of action comparing to the existing ones.

In the last two decades, FtsZ was considered as a promising new target for development of next-generation antibacterial agents. FtsZ is a highly conserved protein among bacteria and it plays an essential role in bacterial cell division. The inhibition of FtsZ activity causes the inhibition of bacterial cell division and disruption of septum formation, leading to cell death. New types of FtsZ inhibitors therefore have been investigated actively for their antibacterial activity against various bacterial strains. Moreover, extensive investigations have been conducted on the structures and functions of the FtsZ protein based on its structural and molecular biology. The findings can be translated into structure-based drug discovery through exploiting computational biology tools.

As discussed above, various FtsZ inhibitors are potentially leads for further structural modification and biochemical investigation. The benzamide 
derivative PC190723 [91] shows a strong antibacterial activity against various $S$. aureus strains. Because of its poor drug-like properties, some powerful prodrugs were developed based on the PC190723, and these compounds are efficacious in the infectious animal model $[96,124]$. On the other hand, natural products are regarded as abundant sources for the drug discovery. For berberine [75], identified as FtsZ inhibitor, its structural modification has produced several compounds with potent antibacterial activity against both Gram-positive and Gram-negative strains. In addition, these derivatives were found to possess a better inhibitory effect on the FtsZ activity compared with their parent compound [76,104]. Moreover, the development of target validation assays and efficient screening methods would also accelerate the discovery of FtsZ targeting compounds from natural source.

Although some FtsZ inhibitors have been known to possess potent antibacterial activity, no one has emerged for clinical trial yet. The discovery of FtsZ targeting compounds seems to be trapped in the very early stages. One possible reason is that the structural information on FtsZ co-crystals with inhibitors is still insufficient. Although more than 30 crystal structures of FtsZ have been collected in the Protein Data Bank, around $30 \%$ of them are from $S$. aureus, and only PC 190723 and its analogs have the co-complex with S. aureus FtsZ [25,125], which provides limited information on how FtsZ inhibitors interact with FtsZ and affect the FtsZ function. PC190723 locates in the interdomain cleft between C-terminal and $\mathrm{H} 7$ helix of FtsZ in a flat orientation and performs to stabilize the FtsZ assembly by shifting the $\mathrm{H} 7$ helix. Nonetheless, due to the lack of crystallographic data, it is difficult to develop better inhibitors based on current structural biology results. In fact, additional interaction information about FtsZ binding to its inhibitors could provide important insights into molecular design of inhibitors.

In conclusion, FtsZ has been considered as an excellent drug target for development of antibacterial agents and extensive efforts have been contributed on searching for potent FtsZ inhibitors as the next-generation antibiotics. Accordingly, we are optimistic that that a handful of clinical candidates could be developed in the coming future.

\section{REFERENCES}

1. C.A. Arias, B.E. Murray, N. Engl. J. Med. 360 (2009) 439-443.

2. D.J. Payne, M.N. Gwynn, D.J. Holmes, D.L. Pompliano, Nat. Rev. Drug. Discov. 6 (2007) 29-40.

3. L.L. Silver, Clin. Microbiol. Rev. 24 (2011) 71-109.

4. G.D. Wright, Chem. Biol. 19 (2012) 3-10.

5. I.M. Gould, M.Z. David, S. Esposito, J. Garau, G. Lina, T. Mazzei, G. Peters, Int. J. Antimicrob. Agents 39 (2012) 96-104.

6. R.M. Humphries, S. Pollett, G. Sakoulas, Clin. Microbiol. Rev. 26 (2013) 759780. 
7. K.K. Kumarasamy, M.A. Toleman, T.R. Walsh, J. Bagaria, F. Butt, R.

Balakrishnan, U. Chaudhary, M. Doumith, C.G. Giske, S. Irfan, P. Krishnan, A.V. Kumar, S. Maharjan, S. Mushtaq, T. Noorie, D.L. Paterson, A. Pearson, C. Perry, R. Pike, B. Rao, U. Ray, J.B. Sarma, M. Sharma, E. Sheridan, M.A. Thirunarayan, J. Turton, S. Upadhyay, M. Warner, W. Welfare, D.M. Livermore, N. Woodford, Lancet Infect. Dis. 10 (2010) 597-602.

8. T.R. Walsh, J. Weeks, D.M. Livermore, M.A. Toleman, Lancet Infect. Dis. 11 (2011) 355-362.

9. G. Devasahayam, W.M. Scheld, P.S. Hoffman, Expert Opin. Investig. Drugs 19 (2010) 215-234.

10. H.P. Erickson, Cell 80 (1995) 367-370.

11. H.P. Erickson, Trends Cell Biol. 7 (1997) 362-367.

12. W. Margolin, FEMS Microbiol. Rev. 24 (2000) 531-548.

13. S.G. Addinall, B. Holland, J. Mol. Biol. 318 (2002) 219-236.

14. E.F. Bi, J. Lutkenhaus, Nature 354 (1991) 161-164.

15. M.A. Oliva, S.C. Cordell, J. Lowe, Nature Struct. Molec. Biol. 11 (2004) 12431250.

16. Y. Li, J. Hsin, L.Y. Zhao, Y.W. Cheng, W.N. Shang, K.C. Huang, H.W. Wang, S. Ye, Science 341 (2013) 392-395.

17. W. Margolin, Nat. Rev. Mol. Cell. Biol. 6 (2005) 862-871.

18. D.W. Adams, J. Errington, Nat. Rev. Microbiol. 7 (2009) 642-653.

19. E. Nogales, K.H. Downing, L.A. Amos, J. Lowe, Nat. Struct. Biol. 5 (1998) 451458.

20. J. Lowe, L.A. Amos, Nature 391 (1998) 203-206.

21. K. Yan, K.H. Pearce, D.J. Payne, Biochem. Biophys. Res. Commun. 270 (2000) 387-392.

22. M. Loose, T.J. Mitchison, Nat. Cell Biol. 16 (2014) 38-46.

23. L. Mosyak, Y. Zhang, E. Glasfeld, S. Haney, M. Stahl, J. Seehra, W.S. Somer, EMBO J. 19 (2000) 3179-3191.

24. K. Sundararajan, A. Miguel, S.M. Desmarais, E.L. Meier, K. Casey Huang, E.D. Goley. Nat. Commun. 6 (2015) 7281.

25. C.M. Tan, A.G. Therien, J. Lu, S.H. Lee, A. Caron, C.J. Gill, C. Lebeau-Jacob, L. Benton-Perdomo, J.M. Monteiro, P.M. Pereira, N.L. Elsen, J. Wu, K. Deschamps, M. Petcu, S. Wong, E. Daigneault, S. Kramer, L.Z. Liang, E. Maxwell, D. Claveau, J. Vaillancourt, K. Skorey, J. Tam, H. Wang, T.C. Meredith, S. Sillaots, L. WangJarantow, Y. Ramtohul, E. Langlois, F. Landry, J.C. Reid, G. Parthasarathy, S. Sharma, A. Baryshnikova, K.J. Lumb, M.G. Pinho, S.M. Soisson, T. Roemer, Sci. Transl. Med. 4 (2012) 126-135.

26. E. Nogales, S.G. Wolf, K.H. Downing, Nature 391 (1998) 199-203.

27. D.J. Scheffers, J.G. de Wit, T. den Blaauwen, A.J. Driessen, FEBS Lett. 494 (2001) 34-37.

28. L.A. Amos, F. van den Ent, J. Lowe, Curr. Opin. Cell Biol. 16 (2004) 24-31.

29. A. Mukherjee, J. Lutkenhaus, J. Bacteriol. 176 (1994) 2754-2758.

30. S. Rueda, M. Vicente, J. Mingorance, J. Bacteriol. 185 (2003) 3344-3351.

31. B. Geissler, D. Elraheb, W. Margolin, Proc. Natl. Acad. Sci. U. S. A. 100 (2003) 4197-4202.

32. S. Pichoff, J. Lutkenhaus, EMBO J. 21 (2002) 685-693.

33. X. Yang, Z. Lyu, A. Miguel, R. McQuillen, K.C. Huang, J. Xiao, Science 355 (2017) 744-747. 
34. A.W. Bisson-Filho, Y.P. Hsu, G.R. Squyres, E. Kuru, F. Wu, C. Jukes, Y. Sun, C. Dekker, S. Holden, M.S. VanNieuwenhze, Y.V. Brun, E.C. Garner, Science 355 (2017) 739-743.

35. J.M. de Pereda, D. Leynadier, J.A. Evangelio, P. Chacon, J.M. Andreu, Biochemistry 35 (1996) 14203-14215.

36. S. Huecas, O. Llorca, J. Boskovic, J. Martin-Benito, J.M. Valpuesta, J.M. Andreu, Biophys. J. 94 (2008) 1796-1806.

37. S. Huecas, C. Schaffner-Barbero, W. Garcia, H. Yebenes, J.M. Palacios, J.F. Diaz, M. Menendez, J.M. Andreu, J. Biol. Chem. 282 (2007) 37515-37528.

38. J. Lowe, F. van den Ent, L.A. Amos, Annu. Rev. Biophys. Biomol. Struct. 33 (2004) 177-198.

39. K.A. Michie, J. Lowe, Annu. Rev. Biochem. 75 (2006) 467-492.

40. A.K. Leung, E. Lucile White, L.J. Ross, R.C. Reynolds, J.A. DeVito, D.W. Borhani, J. Mol. Biol. 342 (2004) 953-970.

41. S. Thanedar, W. Margolin, Curr. Biol. 14 (2004) 1167-1173.

42. N.W. Goehring, J. Beckwith, Curr. Biol. 15 (2005) R514-526.

43. J. Moller-Jensen, J. Lowe, Curr. Opin. Cell. Biol. 17 (2005) 75-81.

44. J. Errington, Nat. Cell. Biol. 5 (2003) 175-178.

45. J. Errington, R.A. Daniel, D.J. Scheffers, Microbiol. Mol. Biol. Rev. 67 (2003) 5265 , table of contents.

46. C. Lu, J. Stricker, H.P. Erickson, Cell. Motil. Cytoskeleton 40 (1998) 71-86.

47. D.E. Anderson, F.J. Gueiros-Filho, H.P. Erickson, J. Bacteriol. 186 (2004) 57755781.

48. L. Romberg, P.A. Levin, Annu. Rev. Microbiol. 57 (2003) 125-154.

49. D.S. Weiss, Mol. Microbiol. 54 (2004) 588-597.

50. Y. Chen, K. Bjornson, S.D. Redick, H.P. Erickson, Biophys. J. 88 (2005) 505-514.

51. A. Dajkovic, A. Mukherjee, J. Lutkenhaus, J. Bacteriol. 190 (2008) 2513-2526.

52. A. Mukherjee, J. Lutkenhaus, EMBO J. 17 (1998) 462-469.

53. L. Romberg, T.J. Mitchison, Biochemistry 43 (2004) 282-288.

54. L. Romberg, M. Simon, H.P. Erickson, J. Biol. Chem. 276 (2001) 11743-11753.

55. S. Huecas, J.M. Andreu, FEBS Lett. 569 (2004) 43-48.

56. M.R. Caplan, H.P. Erickson, J. Biol. Chem. 278 (2003) 13784-13788.

57. M.A. Oliva, S. Huecas, J.M. Palacios, J. Martin-Benito, J.M. Valpuesta, J.M. Andreu, J. Biol. Chem. 278 (2003) 33562-33570.

58. D. Popp, M. Iwasa, H.P. Erickson, A. Narita, Y. Maeda, R.C. Robinson, J. Biol. Chem. 285 (2010) 11281-11289.

59. J. Lowe, L.A. Amos, EMBO J. 18 (1999) 2364-2371.

60. C. Lu, M. Reedy, H.P. Erickson, J. Bacteriol. 182 (2000) 164-170.

61. Z. Li, M.J. Trimble, Y.V. Brun, G.J. Jensen, EMBO J. 26 (2007) 4694-4708.

62. A. Mukherjee, C. Saez, J. Lutkenhaus, J. Bacteriol. 183 (2001) 7190-7197.

63. M.A. Oliva, D. Trambaiolo, J. Lowe, J. Mol. Biol. 373 (2007) 1229-1242.

64. H.P. Erickson, D.E. Anderson, M. Osawa, Microbiol. Mol. Biol. Rev. 74 (2010) 504-528.

65. M. Krupka, W. Margolin, F1000Res. 7 (2018) 235.

66. T.K. Beuria, S.S. Krishnakumar, S. Sahar, N. Singh, K. Gupta, M. Meshram, D. Panda, Biol. Chem. 278 (2003) 3735-3741.

67. X.C. Yu, W. Margolin, EMBO J. 16 (1997) 5455-5463.

68. T.K. Beuria, J.H. Shah, M.K. Santra, V. Kumar, D. Panda, Int. J. Biol. Macromol. 40 (2006) 30-39. 
69. S. Vaughan, B. Wickstead, K. Gull, S.G. Addinall, J. Mol. Evol. 58 (2004) 19-29.

70. M.M. Leger, M. Petru, V. Zarsky, L. Eme, C. Vlcek, T. Harding, B.F. Lang, M. Elias, P. Dolezal, A.J. Roger, Proc. Natl. Acad. Sci. USA, 112 (2015) 10239-10246.

71. K.A. Hurley, T.M. Santos, G.M. Nepomuceno, V. Huynh, J.T. Shaw, D.B. Weibel, J. Med. Chem. 59 (2016) 6975-6998.

72. P. Sass, H. Brotz-Oesterhelt, Curr. Opin. Microbiol.16 (2013) 522-530.

73. C. Schaffner-Barbero, M. Martín-Fontecha, P. Chacón, J.M. Andreu, ACS Chem. Biol. 7 (2012) 269-277.

74. N. Sun, Y.Y. Zheng, R.L. Du, S.Y. Cai, K. Zhang, L.Y. So, K.C. Cheung, C. Zhuo, Y.J. Lu, K.Y. Wong, Medchemcomm. 8 (2017) 1909-1913.

75. P.N. Domadia, A. Bhunia, J. Sivaraman, S. Swarup, D. Dasgupta, Biochemistry 47 (2008) 3225-3234.

76. N. Sun, F.-Y. Chan, Y.-J. Lu, M.A.C. Neves, H.-K. Lui, Y. Wang, K.-Y. Chow, K.-F. Chan, S.-C. Yan, Y.-C. Leung, R. Abagyan, T.-H. Chan, K.-Y. Wong, PLoS ONE 9 (2014) e97514.

77. P. Domadia, S. Swarup, A. Bhunia, J. Sivaraman, D. Dasgupta, Biochem. Pharmacol. 74 (2007) 831-840.

78. X. Li, J. Sheng, G. Huang, R. Ma, F. Yin, D. Song, C. Zhao, S. Ma, Eur. J. Med. Chem. 97 (2015) 32-41.

79. A. Plaza, J.L. Keffer, G. Bifulco, J.R. Lloyd, C.A. Bewley, J. Am. Chem. Soc. 132 (2010) 9069-9077.

80. J.L. Keffer, S. Huecas, J.T. Hammill, P. Wipf, J.M. Andreu, C.A. Bewley, Bioorg. Med. Chem. 21 (2013) 5673-5678.

81. D. Rai, J.K. Singh, N. Roy, D. Panda, Biochem. J. 410 (2008) 147-155.

82. S. Kaur, N.H. Modi, D. Panda, N. Roy, Eur. J. Med. Chem. 45 (2010) 4209-4214.

83. J. Wang, A. Galgoci, S. Kodali, K.B. Herath, H. Jayasuriya, K. Dorso, F. Vicente, A. Gonzalez, D. Cully, D. Bramhill, S. Singh, J. Biol. Chem. 278 (2003) 4442444428.

84. S. Duggirala, R.P. Nankar, S. Rajendran, M. Doble, Appl. Biochem. Biotechnol. 174 (2014) 283-296.

85. A. Bhattacharya, B. Jindal, P. Singh, A. Datta, D. Panda, FEBS J. 280 (2013) 4585-4599.

86. R. Puupponen-Pimia, L. Nohynek, C. Meier, M. Kahkonen, M. Heinonen, A. Hopia, K.M. Oksman-Caldentey, J. Appl. Microbiol. 90 (2001) 494-507.

87. S. Hemaiswarya, R. Soudaminikkutty, M.L. Narasumani, M. Doble, J. Med. Microbiol. 60 (2011) 1317-1325.

88. C.D. Hufford, W.L. Lasswell, Jr., Lloydia 41 (1978) 156-160.

89. S. Urgaonkar, H.S. La Pierre, I. Meir, H. Lund, D. RayChaudhuri, J.T. Shaw, Org. Lett. 7 (2005) 5609-5612.

90. Y. Ohashi, Y. Chijiiwa, K. Suzuki, K. Takahashi, H. Nanamiya, T. Sato, Y. Hosoya, K. Ochi, F. Kawamura, J. Bacteriol. 181 (1999) 1348-1351.

91. D.J. Haydon, N.R. Stokes, R. Ure, G. Galbraith, J.M. Bennett, D.R. Brown, P.J. Baker, V.V. Barynin, D.W. Rice, S.E. Sedelnikova, J.R. Heal, J.M. Sheridan, S.T. Aiwale, P.K. Chauhan, A. Srivastava, A. Taneja, I. Collins, J. Errington, L.G. Czaplewski, Science 321 (2008) 1673-1675.

92. J.M. Andreu, C. Schaffner-Barbero, S. Huecas, D. Alonso, M.L. Lopez-Rodriguez, L.B. Ruiz-Avila, R. Nunez-Ramirez, O. Llorca, A.J. Martin-Galiano, J. Biol. Chem. 285 (2010) 14239-14246. 
93. N.L. Elsen, J. Lu, G. Parthasarathy, J.C. Reid, S. Sharma, S.M. Soisson, K.J. Lumb, J. Am. Chem. Soc. 134 (2012) 12342-12345.

94. N.R. Stokes, N. Baker, J.M. Bennett, J. Berry, I. Collins, L.G. Czaplewski, A. Logan, R. Macdonald, L. MacLeod, H. Peasley, J.P. Mitchell, N. Nayal, A. Yadav, A. Srivastava, D.J. Haydon, Antimicrob. Agents Chemother. 57 (2013) 317-325.

95. N.R. Stokes, N. Baker, J.M. Bennett, P.K. Chauhan, I. Collins, D.T. Davies, M. Gavade, D. Kumar, P. Lancett, R. Macdonald, L. Macleod, A. Mahajan, J.P. Mitchell, N. Nayal, Y.N. Nayal, G.R. Pitt, M. Singh, A. Yadav, A. Srivastava, L.G. Czaplewski, D.J. Haydon, Bioorg. Med. Chem. Lett. 24 (2014) 353-359.

96. M. Kaul, L. Mark, Y.Z. Zhang, A.K. Parhi, E.J. LaVoie, D.S. Pilch, Biochem. Pharmacol. 86 (2013) 1699-1707.

97. M. Kaul, L. Mark, Y.Z. Zhang, A.K. Parhi, Y.L. Lyu, J. Pawlak, S. Saravolatz, L.D. Saravolatz, M.P. Weinstein, E.J. LaVoie, D.S. Pilch, Antimicrob. Agents Chemother. 59 (2015) 4845-4855.

98. L.B. Ruiz-Avila, S. Huecas, M. Artola, A. Vergoñós, E. Ramírez-Aportela, E. Cercenado, I. Barasoain, H. Vázquez-Villa, M. Martín-Fontecha, P. Chacón, M.L. López-Rodríguez, J.M. Andreu, ACS Chem.Biol. 8 (2013) 2072-2083.

99. M. Artola, L.B. Ruiz-Avila, A. Vergonos, S. Huecas, L. Araujo-Bazan, M. MartinFontecha, H. Vazquez-Villa, C. Turrado, E. Ramirez-Aportela, A. Hoegl, M. Nodwell, I. Barasoain, P. Chacon, S.A. Sieber, J.M. Andreu, M.L. LopezRodriguez, ACS Chem. Biol. 10 (2015) 834-843.

100. F.Y. Chan, N. Sun, M.A.C. Neves, P.C.H. Lam, W.H. Chung, L.K. Wong, H.Y. Chow, D.L. Ma, P.H. Chan, Y.C. Leung, T.H. Chan, R. Abagyan, K.Y. Wong, J. Chem. Inf. Model 53 (2013) 2131-2140.

101. F.Y. Chan, N. Sun, Y.C. Leung, K.Y. Wong, J. Antibiot. 68 (2015) 253-258.

102. K.F. Chan, N. Sun, S.C. Yan, L.K. Wong, H.K. Lui, K.C. Cheung, J. Yuan, F.Y. Chan, Z.W. Zheng, W.C. Chan, S. Chen, Y.C. Leung, T.H. Chan, K.Y. Wong, ACS Omega 2 (2017) 7281-7292.

103. A. Parhi, S. Lu, C. Kelley, M. Kaul, D.S. Pilch, E.J. LaVoie, Bioorg. Med. Chem. Lett. 22 (2012) 6962-6966.

104. C. Kelley, Y. Zhang, A. Parhi, M. Kaul, D.S. Pilch, E.J. LaVoie, Med. Chem. 20 (2012) 7012-7029.

105. N. Sun, Y.J. Lu, F.Y. Chan, R.L. Du, Y.Y. Zheng, K. Zhang, L.Y. So, R. Abagyan, C. Zhuo, Y.C. Leung, K.Y. Wong, Front Microbiol. 8 (2017) 855.

106. N. Sun, R.L. Du, Y.Y. Zheng, B.H. Huang, Q. Guo, R.F. Zhang, K.Y. Wong, Y.J. Lu, Eur. J. Med. Chem. 135 (2017) 1-11.

107. T.K. Beuria, P. Singh, A. Surolia, D. Panda, Biochem. J. 423 (2009) 61-69.

108. P. Singh, B. Jindal, A. Surolia, D. Panda, Biochemistry 51 (2012) 5434-5442.

109. R.C. Reynolds, S. Srivastava, L.J. Ross, W.J. Suling, E.L. White, Bioorg. Med. Chem. Lett. 14 (2004) 3161-3164.

110. B. Mathew, S. Srivastava, L.J. Ross, W.J. Suling, E.L. White, L.K. Woolhiser, A.J. Lenaerts, R.C. Reynolds, Bioorg. Med. Chem. 19 (2011) 7120-7128.

111. D.N. Margalit, L. Romberg, R.B. Mets, A.M. Hebert, T.J. Mitchison, M.W. Kirschner, D. Ray Chaudhuri, Proc. Natl. Acad. Sci. USA 101 (2004) 1182111826.

112. D.E. Anderson, M.B. Kim, J.T. Moore, T.E. O'Brien, N.A. Sorto, C.I. Grove, L.L. Lackner, J.B. Ames, J.T. Shaw, ACS Chem. Biol. 7 (2012) 1918-1928. 
113. G.M. Nepomuceno, K.M. Chan, V. Huynh, K.S. Martin, J.T. Moore, T.E. O'Brien, L.A. Pollo, F.J. Sarabia, C. Tadeus, Z. Yao, D.E. Anderson, J.B. Ames, J.T. Shaw, ACS Med. Chem. Lett. 6 (2015) 308-312.

114. D. Singh, A. Bhattacharya, A. Rai, H.P. Dhaked, D. Awasthi, I. Ojima, D. Panda, Biochemistry 53 (2014) 2979-2992.

115. Q. Huang, F. Kirikae, T. Kirikae, A. Pepe, A. Amin, L. Respicio, R.A. Slayden, P.J. Tonge, I. Ojima, J. Med. Chem. 49 (2006) 463-466.

116. M. Sarcina, C.W. Mullineaux, FEMS Microbiol. Lett. 191 (2000) 25-29.

117. R.A. Slayden, D.L. Knudson, J.T. Belisle, Microbiology 152 (2006) 1789-1797.

118. K. Kumar, D. Awasthi, S.Y. Lee, I. Zanardi, B. Ruzsicska, S. Knudson, P.J. Tonge, R.A. Slayden, I. Ojima, J. Med. Chem. 54 (2011) 374-381.

119. D. Awasthi, K. Kumar, S.E. Knudson, R.A. Slayden, I. Ojima, J. Med. Chem. 56 (2013) 9756-9770.

120. S.E. Knudson, K. Kumar, D. Awasthi, I. Ojima, R.A. Slayden, Tuberculosis (Edinb) 94 (2014) 271-276.

121. C.M. Rosenberger, R.L. Gallo, B.B. Finla, Proc. Natl. Acad. Sci. USA 101 (2004) 2422-2427.

122. S. Ray, H.P. Dhaked, D. Panda, Biochemistry 53 (2014) 6426-6429.

123. S. Pieraccini, S. Rendine, C. Jobichen, P. Domadia, J. Sivaraman, P. Francescato, G. Speranza, M. Sironi, Rsc Advances 3 (2013) 1739-1743.

124. M. Kaul, L. Mark, Y.Z. Zhang, A.K. Parhi, E.J. LaVoie, D.S. Pilch, Antimicrob. Agents Chemother. 57 (2013) 5860-5869.

125. J. Fujita, Y. Maeda, E. Mizohata, T. Inoue, M. Kaul, A.K. Parhi, E.J. LaVoie, D.S. Pilch, H. Matsumura, ACS Chem. Biol. 12 (2017) 1947-1955.

(C)2018 by the authors; licensee IAPC, Zagreb, Croatia. This chapter is an open-access publication distributed under the terms and conditions of the Creative Commons Attribution license (http://creativecommons.org/licenses/by/3.0/) (cc) BY 
